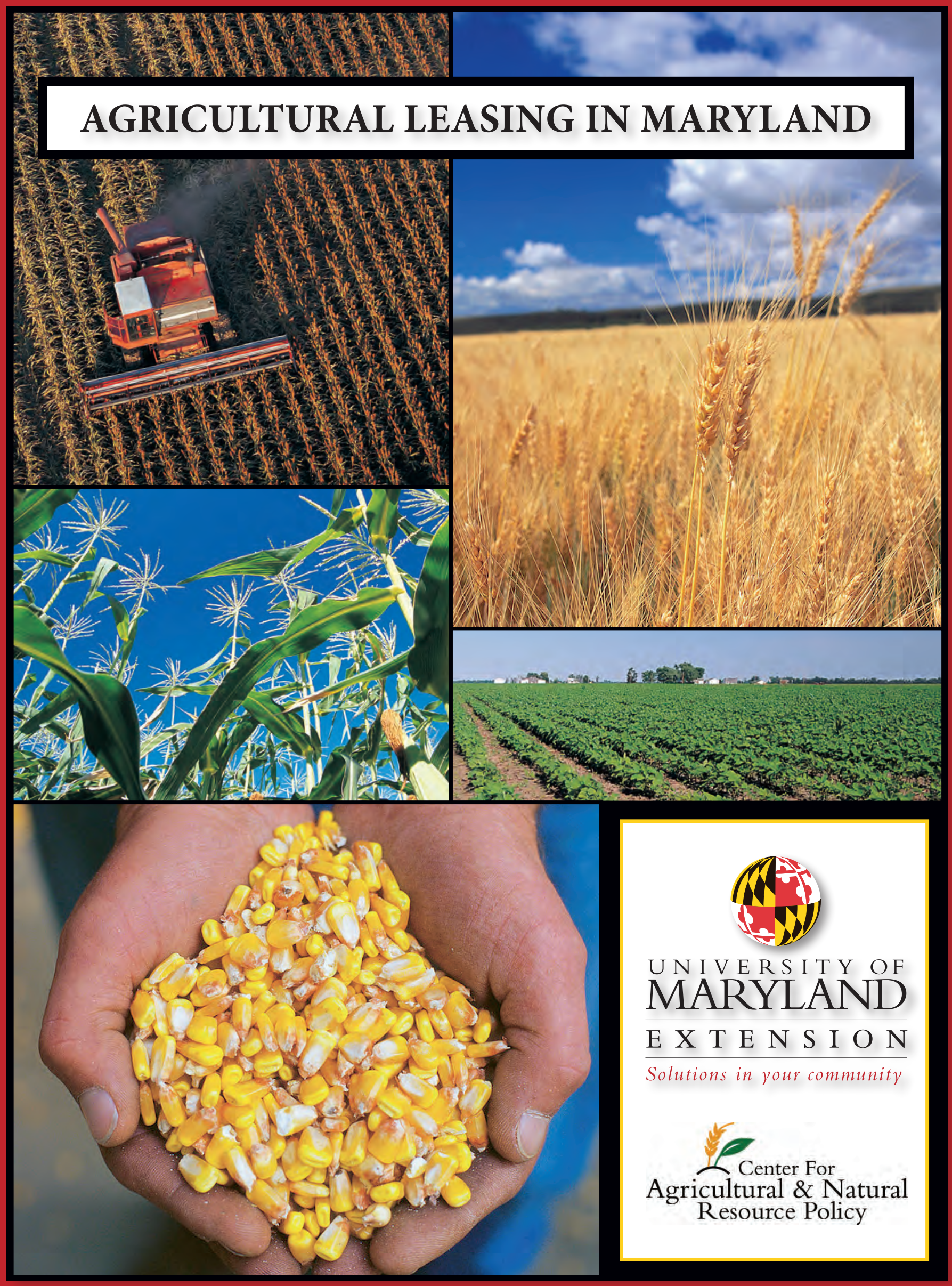



TABLE OF CONTENTS

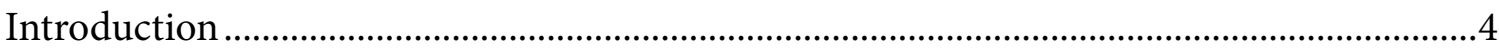

Executive Summary ……………………………………………………………………....

Written versus Oral Leases..........................................................................................6

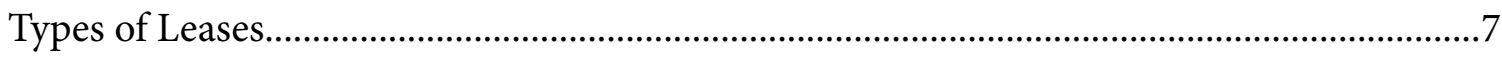

Lease Renewal and Termination ..........................................................................................9

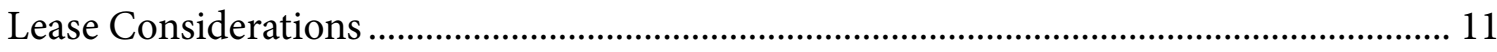

Improvement and Fixtures

Good Husbandry Practices

Death of Tenant/Landlord

Right of Reentry

Third Party Contractors

Amending the Lease

Noxious Weed Control

Repairs

Details Outside the Lease ………………………………………………………………..... 13

Recording Leases

Insurance

Lease Assignments and Subleases

Failure to Pay Rent

Financial Failure of Landlord/Tenant

Recreational Use on Rented Property

Mineral and Wind Leasing

Summary

References 17

Common Terminology Used in Property Leasing ................................................................ 18

Sample Maryland Fixed Cash Rent Farm Lease.......................................................................... 19

Sample Maryland Crop-Share Rent Farm Lease …………………………………………..... 25

Sample Maryland Flex Cash Rent Farm Lease ……………………………………………... 32

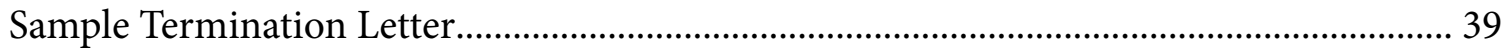

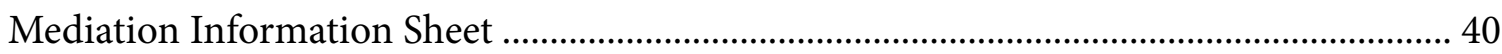

\section{Project partners:}

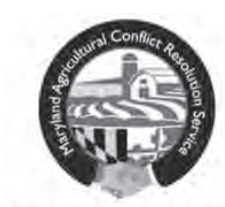

Farm, Agricultural \& Rural Mediation Services
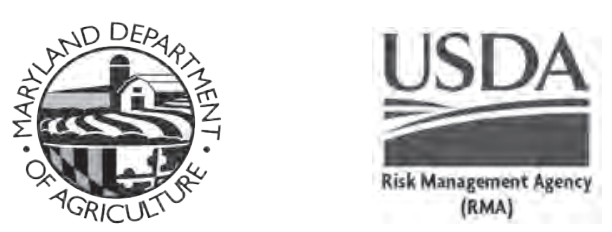

\section{(1)}

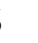

\section{(n)}

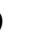
1 3 


\section{Agricultural Leasing in Maryland}

Published in January 2013

\section{By: Paul Goeringer, Research Associate, Center for Agricultural and Natural Resource Policy}

Note: This publication is intended to provide general information about legal issues in agricultural leasing and should not be construed as providing legal advice. It should not be cited or relied upon as legal authority. State laws vary and no attempt is made to discuss laws of states other than Maryland. For advice about how the issues discussed here might apply to your individual situation, you should consult an attorney.

\section{Introduction}

According to USDA's National Agricultural Statistic Service (NASS), agricultural producers lease over 42 percent of all agricultural land in Maryland, or 865,692 acres in 2007 (Ag Census, 2007). Leases for agricultural real estate, equipment, and/or livestock take different forms to meet the needs of the landlord and the tenant. This guide provides an overview of various land leasing issues facing agricultural landowners and agricultural land tenants and raises issues important from both a landowner's and tenant farmer's perspective. Subjects discussed here include:

- The general legal enforceability of both oral and written leases;

- Common types of agricultural leases;

- $\quad$ The renewal and termination of leasing arrangements;

- Death of the landlord or tenant;

- The landlord's right of reentry onto leased premises during the leased period;

- The responsibility for repairs of the leased premises;

- Noxious weed control;

- Insurance issues;

- Failure to pay rent and how a landowner can protect himself;

- Bankruptcy of the landlord or tenant; and

- Lease language that parties should consider when a leased property is subject to multiple economic uses such as hunting, mineral development, or wind energy. 


\section{Executive Summary}

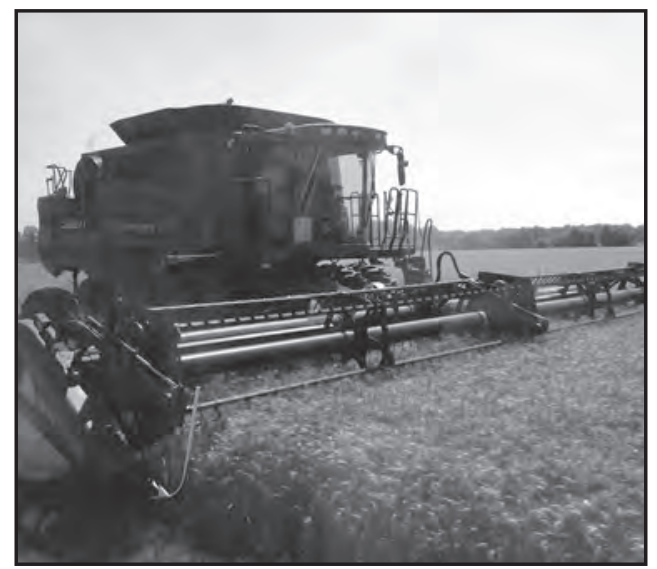

Maryland farmers understand the importance of leases in their operations. From land to equipment, Maryland farmers use varying forms of agreements in their business operations. With the leasing of land, leases for a period of less than one year can be oral and there is no requirement the lease be in writing. Even if the lease can be oral, the landlord and tenant should still consider putting the lease in writing to provide both with a written record of the terms agreed to. Any lease longer than one year will be required to be in writing and signed by the parties involved. The tenant will be the one to request a renewal and a landlord can never force a tenant to renew a lease. Termination will depend on either the termination process in the lease or when the lease is silent on termination on state law which requires either the landlord or tenant to give at least 6 months' notice of the desire to terminate the lease. Unless specified in the lease, a landlord retains no right to reenter the property or to allow new tenants to enter the property to begin preparing fields for planting before the current lease terminates. The landlord can specifically request the right to reenter in the lease. Other issues to consider when negotiating a lease are how to split repair costs, which party will be responsible for noxious weed control, and when the tenant will be required to purchase crop insurance or how crop insurance costs will be split, depending on the type of lease the parties have. This publication will provide an overview of some issues to be considered by both landlords and tenants when negotiating lease agreements.

\section{What is a Lease?}

A lease is a legally enforceable contract that allows the owner of real property, equipment and/or livestock to convey the right to use that property to a person in exchange for rent. A lease will need four necessary elements to be considered valid:

1. A valid contract;

2. Payment provision or "how much rent is owed?"

3. The transfer of rights to use and possession, and control of the property to the tenant; and

4. Intent to transfer rights to use, possession, and control of property back to landlord when lease terminates.

A lease demonstrating these four elements will be considered valid.

The lease defines the rights between the parties and defines who is responsible for what over the term of the lease. For instance, the parties can define who is in charge of maintaining fences or other improvements on the property or can specify the types of farming practices that will take place. For example, the landlord can limit the tenant to certain conservation tillage practices on the leased property. Because the lease defines the rights of the two parties, the parties should negotiate clauses that will work best for them both. 


\section{Written versus Oral Leases}

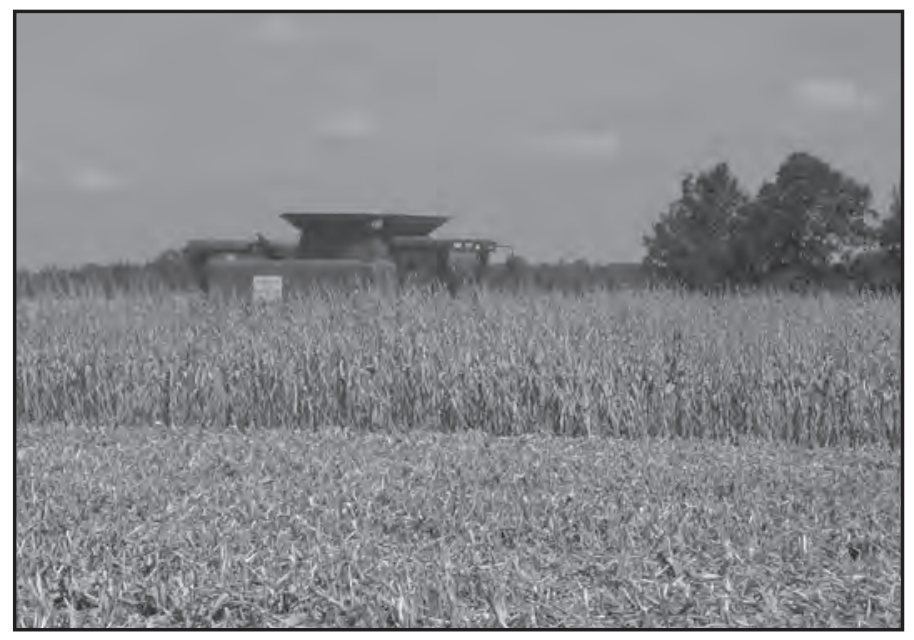

The typical farm lease is oral rather than written. The landowner and the tenant often view a verbal lease as showing trust in one another. Although an oral lease may convey trust, written leases actually record what the two parties have agreed to and as such can avoid misunderstandings. Most oral leases will be valid under Maryland law if they are for one year or less. Oral leases that violate the Maryland's Statute of Frauds will not be valid. The Statute of Frauds requires certain contracts to be in writing and signed by both parties. In Maryland, any lease with a set term longer than one year must be in writing and signed by both parties to be valid. If the landlord orally agrees to rent his farm to a Tenant for one year with an understanding that the lease can be renewed each year, the lease will be valid. This oral lease would be valid since the lease could be performed within one year. Even though the lease can be renewed at the end of the one year period, it does not mean it will be renewed. But if Landlord orally agreed to rent his farm to Tenant for 3 years, this lease must be in writing and signed by both parties to be valid and enforceable in a court of law.

Some exceptions to the Statute of Frauds apply which may render an otherwise invalid oral lease enforceable. One exception is when one of the parties has partially performed in reliance of the oral lease. For instance, Maryland courts ruled in some cases that an otherwise invalid oral agreement will be upheld where a tenant has made payments of rent or has made improvements to the property (Schluderberg, 1929). For example, say the Landlord and Tenant have an oral lease to rent Landlord's farm for three years. Ordinarily, this would be an invalid agreement because it is not in writing. But if Tenant takes over the farm, pays rent on time, and improves the pasture portion of the farm, he has partially performed by paying rents and improving the property. As such the landlord would not be able to argue the oral lease is invalid under the Statute of Frauds. However, a written agreement provides both landlord and tenant greater legal certainty especially when the term exceeds one year.

Getting a court to enforce an oral lease requires a party in court to present evidence as to what constituted the oral agreement - a potentially difficult matter of evidence. All parties present at the time the oral lease was made could be called to testify. The credibility of each witness to the oral lease will need to be established. A court will take the testimony of the witnesses and each witness's credibility into consideration when determining the enforceable terms of an oral lease.

Given the evidentiary difficulties for proving the terms of oral leases and the costs and uncertainties of the court system, written leases can have many obvious advantages over oral leases. Written leases remove the need for the parties to prove the existence of each term in an oral lease. Parties should consider a written lease as a necessity similar to obtaining receipts from input suppliers and other documents to provide parties with a record of other farming transactions. Reducing negotiations to a written document can allow parties to determine the issues that will be driving their leasing relationship. As will be discussed later, parties can define who is responsible for what repairs, how a lease is to be terminated, the types of farming practices to be employed, the crops to be grown, and rights to any growing crops after the formal termination of the lease, etc. 
In addition to giving parties to a lease greater legal certainty, in some cases written leases may be required for other reasons. For instance, lenders may require written leases as proof or verification that a tenant farmer actually does have the acreage he/she claims. Federal and state conservation programs may require a written lease to prove that the tenant has control of the land where conservation practices are to be installed.

\section{Types of Leases}

Landlords and tenants have a variety of lease types from which to choose depending on their various goals. The following discussion is an overview of four common arrangements between landlords and tenants: the cash lease, the flex lease, the crop-share lease, and the custom farming contract. Parties will want to pick the best leasing arrangement that works for their needs.

Under a cash lease or a fixed cash lease, the tenant pays the landlord a cash sum per acre or lump sum for the rights to use the land and other farm resources. For a landlord, a cash rent lease represents a fixed income per year with little involvement in the management of the agricultural operation. Landowners need not concern themselves over the types of crops grown or amount of production costs, nor about price and yield fluctuations. For a tenant, a cash lease allows the tenant to make all the management decisions, provides an incentive for the tenant to reap the highest yields possible, and allows the tenant to retain windfall profits from yield or price increases. ${ }^{1}$

Cash leases face the challenge of determining the right per acre rental rate that should be charged. The two parties can agree to use the current cash rental rate in the area, but cash rental rates can also be set using a variety of factors and the current rate may just be a starting point. Factors in calculating the cash rent rate may include: 1) the amount of federal and state farm program "payment acres;" 2) expected crop returns; 3) improvements on the land and whether or not those improvements (e.g. barn, lots, irrigation, or other fixtures) could be used by the tenant during the lease term; 4) the size of the farm; 5) location of the farm; 6) land quality; and 7) the reputations of the two parties. These factors provide some examples of items that could drive the cash rental rate for the land but others might exist and if so, should be incorporated. Worksheets are available through organizations, such as AgLease101.org, to aid the parties in calculating a fair rental rate. ${ }^{2}$

With cash rent leases, tenant will pay the crop insurance premiums, because the landlord has no interest in crops grown. The tenant will also receive 100 percent of all federal and state farm program payments that may come from the rented farmland. Federal and state farm program regulations require that a party actively participate and take some risk to be eligible for program payments. Under a cash rent lease, a landlord does not meet these requirements.

A hybrid cash rent lease is a flexible cash rent lease or a flex lease. A flex lease is similar to a cash lease in that the landlord charges the tenant an amount per acre. Unlike a cash rent lease, rent under a flex rent lease can fluctuate up or down depending on crop yield, market price, or a combination of both. ${ }^{3}$ A flex lease allows the landlord to gain when market prices or crop yields increase during the crop year. But in return for the possible increase in rental payments, a landlord also loses when market prices or crop yields decrease. Under a flex

\footnotetext{
${ }^{1}$ For a more detailed review of the advantages and disadvantages of a cash lease for either party, see North Central Farm Management Extension Committee, Fixed and Flexible Cash Rental Agreements For Your Farm (Dec. 2011), available at http://aglease101.org/ DocLib/docs/NCFMEC-01.pdf.

${ }^{2}$ See North Central Farm Management Extension Committee, Fixed and Flexible Cash Rental Agreements For Your Farm (Dec. 2011), available at http://aglease101.org/DocLib/docs/NCFMEC-01.pdf.

${ }^{3}$ For information on how to set a flexible rental rate, see North Central Farm Management Extension Committee, Fixed and Flexible Cash Rental Agreements For Your Farm (Dec. 2011), available at http://aglease101.org/DocLib/docs/NCFMEC-01.pdf.
} 
lease, the tenant benefits from the possibility of lower rent payments during low yield or low price years. However the tenant also has to share his gains during high yield or high prices years through higher rental payments.

Under a crop share lease, a tenant pays the landowner a certain percentage of harvested crops. In return, a landlord agrees to allow the tenant to use the land and may pay a percentage of certain input costs. The percentage of crops and the percentage of selected expenses are usually based on local custom. For example, Tenant agrees to crop share rent Landlord's farm for corn production. Terms of such a lease might require Tenant to give Landlord 25 percent of the corn crop produced on Landlord's farm in exchange for the use of the farm and Landlord paying 25 percent of the drying and herbicide costs.

With a crop share lease, both the tenant and landlord would pay crop insurance premiums based on the share of the crop each owns. Federal farm program payments could also be divided based on the crop share, as long as the landlord meets the eligibility requirements. Typically, the landlord and tenant agree upon the division of federal and state farm program payments prior to the current crop year.

Landlords will need to consider the tax implications of each type of lease. Rent paid to a landlord under the terms of a cash rent lease or flexible lease will be reported as income on a landlord's 1040 Form. Similarly, the income from the sale of crops paid to the landlord under a crop share rental arrangement could be taxed on the landlord's 1040 Form if the landowner had not materially participated. Landlords collecting only his share of the crops and paying his share of expenses-but who is not significantly involved in the operation-will likely not be found to be materially participating in the operation.

Alternatively, the income for the sale of the landowner's share of the crop could be considered self-employment earnings if the landlord materially participates in the farming operation. The IRS considers a landlord to have materially participated in the operation when the landlord meets any of the following four tests:

A. Any three of the following:

1. Pay, using cash or credit, toward at least half the direct costs of producing the crop or livestock

2. Furnish at least half the tools, equipment, and livestock used in the production activities

3. Advise or consult with the tenant

B. Inspect the production activities periodically

C. Work 100 hours or more spread over a period of 5 weeks or more in activities connected with agricultural production.

D. Do things that considered in their totality, show you are materially and significantly involved in the production of the farm commodities (IRS, 2011). 
With all these leases, the landlord will be able to deduct expenses for repairs to keep the property in working condition, depreciation on the property, uncollected rents, and operating expenses. For landlords collecting Social Security benefits, rental income will not adversely affect Social Security benefits. An alternative to leasing is a custom farming contract where a landowner contracts with a custom operator to perform all the machine operations on the landowner's land. The landowner takes all the risks involved in the operation and pays the custom operator a set fee for performing the work. The landlord will receive all profits, incur all production costs, pay all crop insurance premiums, and collect 100 percent of eligible federal and state farm program payments. Income earned on the farm will be reported on the landowner's Schedule F. This type of arrangement works well for landowners who still want to control the operation but may not have the time or ability to do the work required. This type of arrangement is also attractive for custom operators - those who wish to earn extra income from the equipment they currently lease or own.

One special note on types of lease agreements: the type of leasing agreement can have federal estate tax implications specifically Internal Revenue Code $\S$ 2032A. Landlords looking to qualifying for this federal estate tax provision need to discuss the implications of various leasing arrangements with an estate tax planning specialist. Current federal estate tax law allows for qualifying agricultural lands' value to be reduced below the fair market value if the land continues in agriculture under a qualifying family member. IRS currently views farms operating under a cash lease as ineligible for this reduction in the land's fair market value. For more information see University of Maryland Extension Factsheet entitled "Estate Planning for Farm Families."

\section{Lease Renewal and Termination}

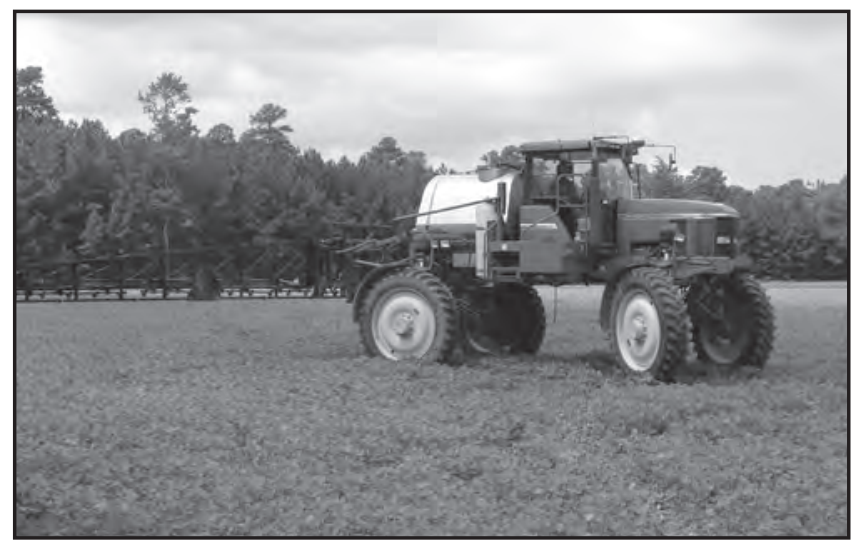

Renewal and termination of a lease depends on the type of tenancy-the type of legal relationship between landlord and tenant-the lease creates. Certain types of tenancies may allow the lease to automatically renew, unless the parties give proper notice of termination. Renewing a lease will always be the responsibility of a tenant. Tenants should be the ones to request a renewal. By contrast, a landlord has the option of either agreeing to the renewal or giving the tenant the proper notice that the lease will terminate at the end of a lease term. Contract provisions may be written to govern the rights of the tenant to renew the lease or the method by which the landlord may exercise her right of termination.

A periodic tenancy has a set period of time such as month-to-month or year-to-year. The periodic tenancy will be classified based on when rent payments are made. For example, if you pay rent once a year, you have a year-to-year periodic tenancy. If you pay rent once a month, you would have a month-to-month tenancy. The typical oral farm lease would be a year-to-year periodic tenancy. Periodic tenancies renew automatically at the end of lease period unless the landlord or tenant gives proper notice of termination. In Maryland, agricultural leases require at least 6 months' 


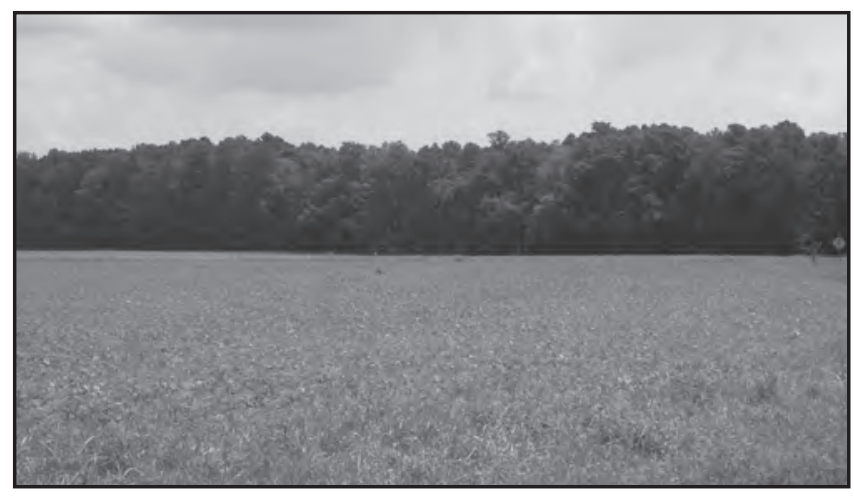

notice to terminate a year-to-year tenancy (Md. Code Real Prop. Section 8-402(b) (4) (2013)). Notice of termination can be given orally or in writing by the landlord to the tenant or by the tenant to the landlord, even with a written lease, unless the lease says it must be in writing (MD. Code Real Prop. Section 8-402(b)(3)-(4) (2013)). Unless proper notice is given, a periodic tenancy will automatically renew at the end of the term. This also means the terms of the original lease will continue to apply until the parties agree to terminate the original terms or the parties agree to a new lease.

Under a tenancy for a term of years, the landlord and tenant agree the lease will end after a certain period of time. For example, Tenant and Landlord sign a lease stating "the lease will run for 4 years from March 1, 2011.” This lease will end on February 28, 2015. A lease for a term of years requires the landowner to give written notice one month before the end of the lease that the landlord desires to repossess the property (Md. Code Real Prop. Section 8-402(b)(1)(i) (2013)). Once the landlord gives notice, the tenant must surrender the property back to the landlord at the end of the term. The tenant can also decide to terminate the lease once the term has expired, but-unlike the landlord-is not required to give notice under Maryland law unless the terms of the written lease require the tenant to do so.

When a tenancy for a term of years renews automatically at the end of its period, the lease typically becomes a periodic tenancy. For example, a lease could state that "the term shall extend from June 1, 2010 to May 31, 2011 or if no written notice is given then the lease will extend as a year-to-year tenancy until properly terminated." In these situations, the tenant and the landlord will be bound by the same duties and rights as stated in the original lease. In other cases, a lease could contain language that only allows renewal if a lease extension, a written document stating the intention to continue the lease, is signed by both parties. If an extension is signed, a landlord's and tenant's rights and duties under the extended lease will be dictated by the terms of the extension.

While parties can specify how the lease will be terminated, both parties must have the same period of time to give notice; one party cannot be given a longer notice period than the other party (Md. Code Real Prop. Section 8-501 (2013)). If the contract specifies how a lease is to be terminated, the exact procedure must be followed; courts are traditionally not forgiving of parties that do not follow the proper notice termination procedures. For example, if the lease states notice should be given "in writing and delivered by certified mail within 6 months before the lease terminates", then notice must be given within 6 months of the end of the lease.

When a lease is for a term of years and the tenant knows when the lease will expire, a tenant will not be able to harvest crops maturing after the lease expires. This rule has long been settled by Maryland courts (Carmine, 1906). Tenants should exercise good judgment before planting crops they know they cannot harvest before the lease expires. The one exception to this rule is when custom and practice in an area allows for harvest after termination or there is an agreement between landlord and tenant to allow the harvest after termination. For example, Tenant plants a fall crop knowing the lease expires before the fall crop will be ready to harvest; the tenant must ask the landlord if tenant can harvest the crop after the termination of the lease. If the landlord does not reply or says nothing, tenant should be entitled to harvest the crops, the landowner's lack of response could be viewed as agreeing. 
A tenant terminating the lease would want to consider setting the termination date with enough time to harvest any growing crops. For example, Tenant has a year-to-year tenancy with Landlord for the past 10 years. Tenant has decided to scale back his operation and sends written notice to the landlord that tenant plans to terminate the lease on May 31. Because a portion of the leased farmland would have crops ready to harvest after May 31, tenant reserves in the termination letter that "termination for the portion of the above described farm with growing fall-seeded crops which was prepared in conformity with normal growing practices in the county, termination will deemed to be the day after following the last day of harvest or August 1, whichever comes first."

\section{Lease Consideration}

\section{Improvement/Fixtures}

A fixture is personal property attached to the land that is regarded as a non-moveable part of the real property. An example of a fixture would include a shed, cattle lots, diesel and oil storage tanks, etc. In Maryland, unless the lease contract specifies otherwise, tenants would have the right to remove any fixtures he has erected on the property once the lease terminates (Md. CODE ReAL Prop. Section 8-114 (2013)). Of course, a tenant does not have the right to remove fixtures which the landlord has placed on the property.

\section{Good Husbandry Practices}

Many state courts and commentators view an agricultural lease as carrying the implied duties that the tenant use good husbandry or good agricultural practices on the leased property (Hamilton, 1990). Good husbandry practices conserve the fertility, usefulness, and value of the soil (Hamilton, 1990). For example, Tenant is using the leased property for cattle and constantly over grazes the leased property damaging the pasture and promoting soil erosion. This agricultural practice would not meet the duty to use good husbandry practices. But if Tenant is properly grazing the leased property and not damaging the property then Tenant would be meeting the duty to use good husbandry practices.

\section{Death of Tenant/Landlord}

The death of a landlord or a tenant does not terminate the lease. If the landlord dies, the tenant's lease continues for the lease term until the lease is properly terminated. The tenant must pay rent to the landlord's estate as it becomes due and the landlord's estate will include any rent payments on its 1040 Form. The executor of the landlord's estate or the heir to the property can decide whether or not to allow the lease to renew or to properly terminate the lease.

\section{Right of Reentry}

By law or by custom, a landlord has no right to enter onto leased property during the lease period. In fact, unless the landlord reserves a right of reentry in the terms of the lease agreement, the landlord could be charged with trespassing for entering the leased premises. Those landlords considering new tenants after the current lease expires or those landlords expecting to prepare the property for a new crop after the expiration of the current lease should reserve a right of reentry in the lease agreement. If a right to reentry has not been reserved in a lease, a tenant has the option to forbid the landlord or new tenants to enter the property to begin tillage operations. Reentry provisions are also important for those landlords wishing to make repairs, improvements, or inspections on the leased property. 
One special note for those tenants producing tobacco on leased property, Maryland law allows a landlord the right to enter the property six months after September 1 to strip, pack, ship, and sell any tobacco on the leased property if the tenant has made no reasonable progress in harvesting the tobacco (Md. Code Real Prop. Section 8-116 (2013)). This will be done at the tenant's expense. Even if the lease does not have a right to reentry a landlord can remove and market grown tobacco under this condition.

\section{Third Party Contractors}

The landlord has no control over third party contractors used by the tenant, such as crop scouts, aerial sprayers, etc. By leasing the property to the tenant, the landlord is giving to the tenant the right to choose who enters the property to perform certain jobs to carry out the lease or agricultural operations. A landlord could try to limit this right, but issues would arise of materially participation in the operation. A landlord choosing to limit the tenant's right to decide who can enter the leased property may be seen as participating in the farm operation. This can have an impact on the landlord's tax situation and other liability issues. A landlord limiting this right could also run afoul of the tenant's implied duty to use good husbandry practices. The tenant employs third party contractors to help maintain the fertility and general usefulness of the soil as well as other good agricultural practices. Before limiting a tenant's rights to allow third parties to enter, a landlord would want to talk with a licensed attorney to fully understand the implications.

\section{Amending the Lease}

At any time during a lease term or after a lease has been renewed, the tenant and landlord can agree to amend the lease. As with all contracts, a lease can be amended to ensure the contractual relationship operates more smoothly. Both parties must agree to any amendments and these should be put in writing, to both provide the parties with a written record and, in many cases, satisfy Maryland’s Statute of Frauds.

\section{Noxious Weed Control}

Noxious weed control presents a legal conundrum under Maryland law. Even if the landlord has no right of reentry during the lease period, he can still be held liable for noxious weed control during that period. This is another reason landlords should include a right of reentry into any lease agreements. Tenants, like landlords, are also legally liable for noxious weed control (MD. Code Ann. Agric. Section 9-404(c) (2013)). In Maryland, noxious weeds are defined to include: 1) Musk, Canada, nodding, plumeless, and bull thistles; 2) Johnson grass; and 3) shatter and wild canes (MD. Code AGric. Section 9-401 (2013)). Because the duty to eradicate noxious weeds falls on both landlord and tenant, lease terms should clearly define who is responsible for what in terms of noxious weed control. For example, Landlord and Tenant negotiate a noxious weed control clause in their lease. The clause requires Landlord to supply the herbicide necessary to control noxious weeds and requires the tenant to apply it. Parties could also consider other solutions for sharing noxious weed control when developing their lease.

\section{Repairs}

A question often arises as to who is responsible for repairs or maintenance required in keeping up the rented property. Traditionally in Maryland, a landlord has no legal duty to make repairs to the rented property (Miller, 1955). A tenant on the other hand, traditionally, was only required make to ordinary repairs to the leased property $(K a t z, 1965)$. Ordinary repairs are those necessary 
to keep the leased property in working condition. Under this traditional view, a landlord would not be required to make any repairs to a leased property during the life of a lease and a tenant would only be required to make those repairs necessary to keep the leased property in working condition. Under the traditional view, a tenant would have a legal duty to perform ordinary repairs on roads running through the property; perform lane scrapings and mowing to keep a leased property in ordinary working condition-all at the tenant's own expense.

This traditional view can be altered by the lease agreement. Thus, the landlord and tenant can specify the types of repairs the landlord will be required to make and the level of maintenance the tenant will be required to do. For example, a lease could specify that the landlord is required to replace broken fences and that the tenant is required to keep all roads passable. The lease agreement could also specify how the tenant will be compensated for making necessary repairs, such as whether the tenant will receive a rent deduction for making repairs or whether the landlord will be required to provide supplies for repairs and the tenant contributes the labor.

\section{Details Outside the Lease}

\section{Recording Leases}

Recording of farm leases is not required under Maryland law. Currently only leases on residential property zoned for four or fewer dwelling units are required to be recorded in the county land records (Md. Code Ann. Real Prop. Section 8-702(a) (2013)). An agricultural lease would not qualify and does not need to be recorded in the county land records.

Farm Service Agency, U. S. Department of Agriculture (FSA) may require an agricultural producer to supply a copy of a written lease in certain cases to qualify for federal and state farm programs. For example, FSA may require the tenant to supply either a written lease proving that the rental arrangement is not a crop-share arrangement or a form signed by the landlord verifying she does not have a claim in the crop. Some programs may require copies of written leases or other documents to prove that the tenant has control of the land. Although not a formal requirement to record a lease, FSA may require a written lease to qualify for certain federal and state farm programs.

\section{Insurance}

Both parties will want to carry liability insurance on the leased property. This is good business practice and will protect both landlord and tenant from possible liability claims. The landlord will want to carry insurance on all structures located on the leased property to protect against loss. The tenant will want to carry insurance on his own personal property located on the leased property. For example, Tenant rents farm from Landlord that has a huge barn and granaries located on the property. Inside the barn, Tenant stores farm equipment and tools. Tenant also stores grain inside the granaries. Landlord would want to insure the barn and the granaries to protect against loss. Tenant would want to insure his equipment and tools located in the barn and any grain located in the granaries.

As discussed earlier, crop insurance coverage will depend on the type of lease the landlord and tenant share. If a fixed cash rent lease or a flex rent lease is used, the tenant will be responsible for insuring the crop. A landlord may want to include a clause in the lease to ensure that the tenant carries a minimum level of crop insurance coverage in order to ensure the tenant can pay the rent. Use of a crop share lease will require the landlord and tenant to split the cost of crop insurance coverage based on the percentage of the crop owned by each party. With a custom farming contract, the landowner will need to insure the entire crop. 


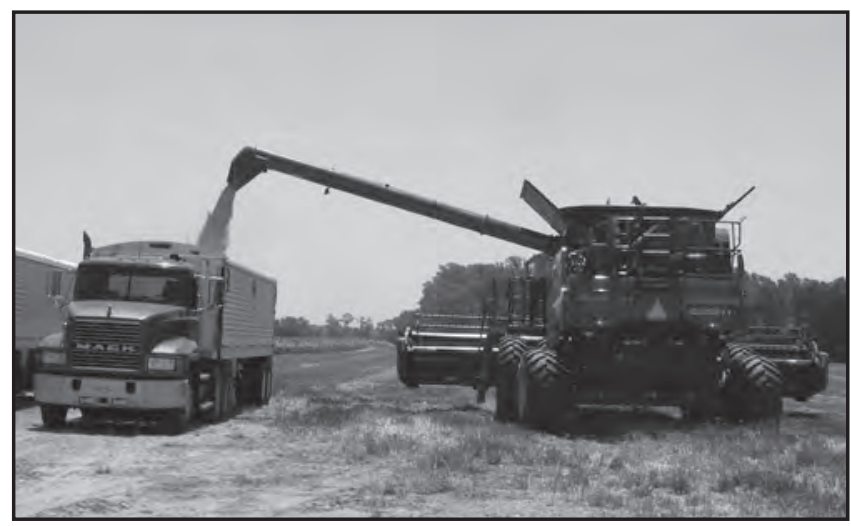

An assignment is when a tenant signs his/her rights and duties under the lease to a third party. In effect, the third party becomes the tenant, takes control of the rental property, and fulfills any duties owed to the landlord. By contrast, a sublease is when a tenant assigns part of the remaining term of the lease to a third party and the original tenant holds a right of reversion, an interest in the property, when the sublease expires. For example, Tenant's lease has 6 months remaining and Tenant sublets the leased property to Third Party for the next four months. At the end of the four months, Tenant will regain the leased property for the last two months on the lease.

Traditionally, tenant has the right to assign or sublet the lease to any third party without the consent of the landlord (Julian, 1990). This right can be limited by the terms of the lease, although courts tend to dislike clauses preventing assignments or subleasing. Nevertheless, if properly drafted, a lease agreement can prohibit assignments or subleasing or require consent of the landlord before an assignment or sublease occurs.

\section{Failure to Pay Rent}

Maryland law does provide some protections for landlords when a tenant fails to pay rent. With a cash rent lease or a flex rent lease, landlords will not have an automatic statutory liens for unpaid rent. When a tenant has failed to pay rent for three months with a tenancy for a term of years or failed to pay rent for a periodic tenancy that has continued for more than three months a landlord can file a motion for distress for rent (Md. Code Ann. Real Prop. Section 8-302(c) (2013)). Only if a court grants the motion will a landlord gain a lien on all growing and harvested crops. Obviously, using the court system to try and recoup unpaid rent can be an expensive, long, and laborious process.

A better way for a landlord to protect himself from the risk of unpaid rent is to perfect, validating a security interest by filing a financing statement with the Maryland State Department of Assessments and Taxation, a security interest in the crops. A security interest can be created by the lease and, if filed appropriately with the state and in conformity with other statutory requirements, may give the landlord preference over the tenant's other creditors if the tenant has financial difficulties (MD. CoDE Ann. Real Prop. Section 8-307(a)(6) (2013)). If a landlord has a perfected security interest in the tenant's crops and the tenant fails to pay rent, the local sheriff can remove growing or harvested crops to sell at a public auction to recoup the rent owed (Md. Code Ann. Real Prop. Sections 8-319 to 8-320 (2013)).

If a landlord includes language in the lease to provide a security interest in the crops as collateral for unpaid rent, the lease will need to describe the crops to be taken as collateral, the tenant will need to sign the lease, and the landlord will need to perfect the security interest. Landlords considering including specific language for a security interest for unpaid rent should consider talking with a licensed attorney in their area to make sure all requirements of perfecting their security interest are met. 
While a perfected security interest is the best form of protection for landlords, Maryland law does provide for a lien in growing crops when a crop-share lease is used in some counties. When a crop-share lease is used for rent, a landlord will have a lien for rent in the crops, for all counties except for Calvert, Charles, Prince George's, St. Mary's, and Worcester counties (Md. Code Ann. Real Prop. Section 8-115(a) (2013)). In Calvert, Charles, Prince George's, St. Mary's, and Worcester counties, a lien in growing crops would exist with a crop-share lease and when landlord advances to a tenant are made on the faith that crops are being grown (Md. Code Ann. Real Prop. Section 8-115(b) (2013)). An advance would be any money, production inputs, or equipment the landlord gives to the tenant in return for an additional share in the growing crops. For example, Landlord and Tenant have a cropshare lease and Tenant's banker has reduced Tenant's operating loan. Tenant and Landlord agree that Landlord will advance Tenant the additional capital necessary to produce the crop in return for an extra share of the crop. In these five counties, landlords need to make sure they have a valid agreement for the advance in writing and signed by both parties (MD. CodE Ann. Real Prop. Section 8-115(b) (2013)).

\section{Financial Failure of Landlord/Tenant}

When either a landlord or tenant is facing or has filed for bankruptcy, a lease will continue. In the case of the landlord filing for bankruptcy, the tenant may continue to farm the rented property as if nothing has changed. Or, in the case of the tenant filing for bankruptcy, a tenant will still be able to farm the rented land. A landlord dealing with a bankrupt tenant would want to talk with an attorney to ensure that neither a landlord's nor tenant's rights in bankruptcy are violated.

Even if the lease has language that terminates the lease upon one party becoming insolvent or filing for bankruptcy, this language will be invalided. When a debtor (tenant or landlord who has filed for bankruptcy) files for bankruptcy, an automatic stay or automatic injunction goes into place to preserve the status quo. However, this automatic stay can be lifted by application to the bankruptcy court by a creditor (11 U.S.C. § 362(a)). The automatic stay would allow a tenant to continue operating on the leased property, regardless of who files bankruptcy or the terms of the lease. One exception to the automatic stay is when the lease is a tenancy for a period of years and the lease expires before or during the bankruptcy proceedings. In these cases, bankruptcy courts will allow the lease to terminate (11 U.S.C. § 362(b)(10)).

During a bankruptcy proceeding, bankruptcy courts will be able to approve the rejection of any unexpired lease of a debtor (11 U.S.C. § 365(a)). The purpose of bankruptcy is to allow the debtor a fresh start, and allowing for the rejection of burdensome unexpired leases is one way to accomplish this purpose. For example, Tenant has filed for bankruptcy and has a cash lease with Landlord with a rental rate two times the county rental rate. Tenant may decide to reject this lease because the rental rate is too burdensome on Tenant to allow for a fresh start once the bankruptcy has concluded.

A rejected unexpired lease is viewed as a lease breached on the day the bankruptcy action was filed. The non-breaching landlord or tenant would be able to bring a breach of contract claim against a debtor landlord or tenant. Any damages awarded would be considered a pre-bankruptcy unsecured claim and a non-breaching party may only get pennies on the dollars owed in damages.

When one party files for bankruptcy protection, the other party to the lease should retain an attorney specializing in creditor's rights immediately. The party not filing for bankruptcy will want to ensure that his/her interest is protected without depending on the bankruptcy court. Seeking legal counsel in these situations can prevent large losses or costs in the future. 


\section{Recreational Use on Rented Property}

As stated earlier, a landlord will have no right to enter the property during the life of the lease unless that right was reserved in the lease. This applies also to recreational uses of the property. A landlord will not be able to enter his/her property to hunt, fish, or for any other recreational purpose without reserving that right. Nor may the landlord allow others to use the property for recreational purposes without first reserving the right in the lease.

If a landlord's property has additional value for recreational purposes, the landlord may want to reserve a right of reentry for these recreational purposes. A landlord in this situation should also consider language in the lease limiting a tenant's right to use the land for recreation purposes. A tenant renting land to farm with recreational value should consider language in the lease that requires those entering to shut gates, respect fences, keep vehicles on established roads, and to shoot away from people or livestock. The tenant might also want language requiring for the landlord to pay for any livestock accidentally killed or crops destroyed by the landowner's hunters.

\section{Mineral and Wind Leasing}

Mineral and wind leasing can provide the landowner with additional sources of income. Mineral leasing by the mineral owner (whether the landlord or another third party) could cause issues for a farming tenant. In cases where the mineral owner would like to develop the mineral estate, a tenant will be able to do very little to stop the mineral owner. The mineral estate is the dominant estate-in other words; it prevails over the surface estate, i.e. the farm. The owner of the mineral estate has the right to use the surface as reasonably necessary to extract minerals. The tenant will have some rights to subadjacent support of the surface, the right to have the surface supported in its natural state by the adjoining land and underground structures. If the mining operation will affect the surface of the rented property and interfere unreasonably with the farming operation, a tenant may be able to receive a reduction in the rent owed or maybe able to negotiate a new rental rate.

With oil and gas exploration, the typical lease should include language for the oil or gas company to pay any damages caused to growing crops. If the landowner owes the mineral rights, a farming tenant may want to require the landlord himself to seek compensation for damages to the tenant's crops by the mineral extractions. The tenant may have a harder time collecting damages from third parties. Tenant and landlord would also want to make sure that "growing crop" means the crops or grazing practices currently utilized by a tenant. For example, if Tenant uses the property for grazing cattle. Tenant should make sure that the oil and gas lease clearly defines growing crops to include grasses used for grazing. When the landlord does not own the mineral owner, a tenant may have a harder time collecting for damages caused to a tenant's crop.

In areas of Maryland where leasing to wind energy companies is an option, landlords should consider reserving a right of reentry for the purpose of developing wind energy turbines on their leased property. In order to best protect his rights, a tenant should also consider language that allows the lease to be terminated if wind energy development causes the leased property to become unusable as farmland or greatly impairs the leased property for farming purposes. Such language may aid a tenant whenever a leased property is subject to multiple economic uses. 


\section{Summary}

Leasing land for agricultural production has often been as simple as agreeing to a rental rate, the duration of the lease, and shaking hands. And in many cases, landowner and tenant have been satisfied with the arrangement. However, as outlined above, many situations can arise to cause friction to a relationship based on an oral agreement. Written documents ensure that both parties know exactly what they have decided to occur under a variety of scenarios. Depending on the needs of a landlord and tenant, an agricultural lease can be simple or more complicated. All parties should evaluate their needs and goals in the leasing arrangement and then negotiate for language in the lease that meets those goals. While external requirements for written leases are few, all parties may find using a written lease allows them to include explicit agreements about issues before any problems arise. In addition, a written and signed document increases the legal enforceability of the agreement if a dispute ever arises and cannot be solved amicably.

\section{References}

Calvert Joint Venture \#140 v. Snider, 816 A.2d 854, 874 (Md. 2003).

Carmine v. Bowen, 64 A. 932 (Md. 1906).

Neil D. Hamilton, Adjusting Farm Tenancy Practices to Support Sustainable Agriculture, $12 \mathrm{~J}$. Agric. TAX’n \& Law 226 (1990).

Internal Revenue Service, Publication 225 (2011), Farmer’s Tax Guide (Oct. 17, 2011) available at http://www.irs.gov/pub/irs-pdf/p225.pdf.

Julian v. Christopher, 575 A.2d 735 (Md. 1990).

Katz v. Williams, 211 A.2d 723, 726 (Md. 1965).

Miller v. Howard, 110 A.2d 683 (Md. 1955).

North Central Farm Management Extension Committee, AgLease101.org, available at http:// aglease101.org

North Central Farm Management Extension Committee, Crop Share Rental Agreements For Your Farm (Dec. 2011), available at http://aglease101.org/DocLib/docs/NCFMEC-02.pdf

North Central Farm Management Extension Committee, Fixed and Flexible Cash Rental Agreements For Your Farm (Dec. 2011), available at http://aglease101.org/DocLib/docs/ NCFMEC-01.pdf.

Piedmont \& George’s Creek Coal Co. v. Kearney, 79 A. 1013 (Md. 1911).

Schluderberg v. Dietz,144 A. 774 (Md. 1929). 


\section{COMMON TERMINOLOGY USED IN PROPERTY LEASING}

$>$ Advance - any money, production inputs, or equipment landlord gives tenant in return for an additional share in the growing crops.

$>$ Assignment - when tenant signs his/her rights and duties under the lease to a third party.

$>$ Cash lease or a fixed cash lease - a rental arrangement where a landlord charges a tenant a fixed dollar per acre rental rate to use a farmland.

$>$ Clause - A distinct section in a lease, contract, or any legal document.

$>$ Contract - A legally enforceable agreement between two or more parties creating obligations.

$>$ Crop share lease - a rental arrangement that allows a tenant to pay rent through a certain percentage of crops.

$>$ Custom farming contract - a landowner contracts with a custom operator to perform all the machine operations on the landowner's land

$>$ Fixture - personal property attached to the land that is regarded as a non-moveable part of the real property

$>$ Flexible cash rent lease or a flex lease - A rental agreement that is a hybrid of the cash lease and states that the tenant will pay in proportion to either or both the price and yield level.

$>$ Landlord/Lessor - The person who owns the real or personal property and rents it to the farmer.

$>$ Lease - A type of legally enforceable contract that allows the owner of real property, equipment or livestock to convey the right to use that property to a third person in exchange for rent.

> Perfect - A financing statement filed with the Maryland State Department of Assessments and Taxation to validate the security interest.

$>$ Periodic tenancy - a tenancy that goes for a period such as month-to-month or year-to-year.

$>$ Real Property - Land, anything growing on it, and anything attached or erected on the land that cannot be removed without injury to the land.

$>$ Sublease - when a tenant assigns part of the remaining term of the lease to a third party and the original tenant holds a right of reversion, or an interest in the property, when the sublease expires.

$>$ Tenancy for a term of years - landlord and tenant agree the lease will end after a certain period of time.

$>$ Tenant/Renter/Lessee - A person who has the right to possess the real or personal property under a lease agreement.

$>$ Term - The fixed period of time during which the lease runs.

$>$ Third Party Contractor - A party not subject to the original lease hired by the landlord or tenant to make repairs or do other work on the leased property. 
SAMPLE MARYLAND FIXED CASH RENT FARM LEASE

\section{DIRECTIONS:}

1. Complete two copies of this lease, one for the landlord and one for the tenant.

2. Cross out or delete any unnecessary clauses.

3. Have both parties sign both copies, or sign one lease and make a copy of the signed lease.

4. This lease is provided to aid landlords and tenants in preparing their own written farm leases.

Disclaimer: This lease sample is intended to provide general information and should not be construed as providing legal advice. Using any lease format creates or alters the legal rights between the two parties and both parties should each consider consulting their respective attorneys for clarification on how any clause in a lease affects their respective legal rights.

This lease is based off a fixed cash lease developed by the North Central Farm Management Extension Committee and found at http://aglease101.org/DocLib/docs/NCFMEC-01A.pdf modifications have been made to make the lease more Maryland specific. 


\section{Sample M aryland C ash Lease}

This lease is entered into on , 20 -_---, between:

L andowner(s) (hereinafter Lessor):

whose mailing address is

and

Tenant (s) (hereinafter Lessee):

whose mailing address is

\section{Property Description}

Lessor agrees to rent and lease to L essee, to occupy and to use for agricultural purposes only, the following real estate located in the County of and the State of , and described as follows:

\section{, commonly referred to as the}

Farm and consisting of approximately acres, together with all

buildings and improvements thereon belonging to the Lessor, except

\section{Tenure of L ease}

The term of this lease shall be from , 20 , to , $20 \ldots$. This lease shall continue in effect from year to year thereafter unless written notice of termination is given by either party to the other at least days prior to expiration of this lease or the end of any year of continuation.

\section{No Partnership}

It is agreed that this agreement is one of lease and not of partnership, and Lessor shall not be or become responsible for any debts contracted by L essee. 


\section{M odification of Agreement}

A ny modification of this lease or additional obligation assumed by either party in connection with this lease shall be binding only if placed in writing and signed by each party or an authorized representative of each party.

\section{Assignment and Sublease}

This lease shall inure to the benefit and be binding upon the heirs, executors, successors, and assigns of the parties; provided, however, L essee shall not sublease all or any part of the leased premises, or assign this lease, without the prior, express, and written consent of Lessor; and if L essee does sublease the premises or part of the premises or assign this lease, such sublease or assignment shall be void unless Lessor has given their prior, express, and written consent.

\section{Right to Entry}

Lessor, as well as agents and employees of Lessor, reserve the right to enter the property at any reasonable time to: a) consult with the Lessee; b) make repairs, improvements, and inspections; c) after notice of termination of the lease is given do tillage, seeding, fertilizing, and any other customary seasonal work, including planting a cover crop; and d) hunt and fish wildlife during applicable seasons and according to the laws, rules, and regulations of the $\mathrm{M}$ aryland Department of $\mathrm{N}$ atural R esources, none of which is to interfere with the L essee in carrying out L essee's regular farm operations.

\section{Mineral and Wind/Solar Development}

L essor retains the right to enter into agreements for the development of petroleum, wind, solar, or other resources on the property, and may also authorize third parties to enter the property to survey, construct, and/or operate the facilities reasonably necessary to develop those resources. Lessor agrees to reimburse L essee for any actual damage suffered to crops destroyed by these activities and to release Lessee from obligation to continue farming this property when and if development of such resources interferes materially with Lessee's opportunity to make a satisfactory return.

\section{Cultivation}

Lessee shall cultivate the demised premises according to generally accepted agricultural practices practiced in the County of State of

\section{Noxious W eeds}

Lessee agrees to use diligence to prevent noxious weeds from going to seed on the property.

\section{Repairs}

Lessor and Lessee agree to the following: 
1. Lessee agrees to prevent waste, loss, or damage to the property of Lessor and keep property neat and orderly. Lessee further agrees to keep the building, fences (including hedges), and other improvements in good repair and condition as they are when Lessee takes possession or in as good repair and condition as they may be put by Lessor during the term of the lease - ordinary wear, loss by fire, or unavoidable destruction excepted.

2. Lessor agrees to replace or repair as promptly as possible the dwelling or any other building or equipment regularly used by the operator that may be destroyed or damaged by fire, flood, or other cause beyond the control of the Lessee or to make rental adjustments in lieu of replacements. Lessor further agrees to furnish materials for all normal maintenance and repairs.

\section{Removal of Improvements}

Lessor agrees to let Lessee make minor improvements of a temporary or removable nature, which do not alter the condition or appearance of the property, at the L essee's expense. Lessor further agrees to let the operator remove such improvements even though they are legally fixtures at any time this lease is in effect or within days thereafter, provided the operator leaves in good condition that part of the property from which such improvements are removed. Lessee shall have no right to compensation for improvements that are not removed except as mutually agreed.

\section{M odification of Agreement}

A ny modification of this agreement or additional obligation assumed by either party in connection with this agreement shall be binding only if placed in writing and signed by each party or an authorized representative of each party.

\section{E nvironmental Compliance}

The Lessee shall conduct all operations on the property in a manner consistent with all applicable local, state, and federal environmental codes, regulations, and statutes and shall bear sole responsibility for any violations thereof. The L essee shall be solely responsible for securing any permits or approvals necessary for his or her activities on the property. In the event of any legally prohibited release of materials to the environment, the Lessee will indemnify the Lessor for any costs of environmental cleanup and restoration as well as any penalties, fines, judgments or other amounts incurred by Lessor as a result of such release. 


\section{Conservation}

B oth L essor and L essee agree to implement as far as possible the best management practices recommended by the $\mathrm{N}$ atural Resource Conservation Service and their respective Soil Conservation District with those agencies' soil and water conservation programs.

\section{Mediation}

A Il claims and disputes arising under or relating to this L ease are to be first submitted for mediation through the M aryland A gricultural Conflict Resolution Service. B oth parties shall equally share the mediator's costs and fees. This provision maybe enforced by any court of competent jurisdiction and the party seeking enforcement may seek all costs, fees, and expenses associated with enforcing this provision.

\section{Insurance}

L essee agrees to carry at a minimum \$ in liability insurance on the property. Lessee also agrees to carry a minimum coverage level of crop insurance on any crop produced on the property. Lessee agrees to supply Lessor with Certificates of Insurance and give notice of termination of coverage. Lessee will also name Lessor as an additional insured on any policy on the property.

\section{Fixed C ash Rent}

Less agrees to pay to Lessor the fixed sum of \$ per year. This represents $\$$ per acre for acres of cropland and \$ per acre for

acres of pasture land. Rent shall be due on of of each year until this lease is properly terminated.

\section{Entire Agreement}

This agreement shall constitute the entire agreement between the parties and any prior understanding or representation of any kind preceding the date of this agreement shall not be binding upon either party except to the extent incorporated in this agreement 
Lessor

Lessor

Lessee

Lessee
Date

Date

Date

Date 
SAMPLE MARYLAND CROP-SHARE RENT FARM LEASE

\section{DIRECTIONS:}

1. Complete two copies of this lease, one for the landlord and one for the tenant.

2. Cross out or delete any unnecessary clauses.

3. Have both parties sign both copies, or sign one lease and make a copy of the signed lease.

4. This lease is provided to aid landlords and tenants in preparing their own written farm leases.

Disclaimer: This lease sample is intended to provide general information and should not be construed as providing legal advice. Using any lease format creates or alters the legal rights between the two parties and both parties should each consider consulting their respective attorneys for clarification on how any clause in a lease affects their respective legal rights.

This lease is based off a crop-share lease developed by the North Central Farm Management Extension Committee and found at http://aglease101.org/DocLib/docs/NCFMEC-02A.pdf modifications have been made to make the lease more Maryland specific. 


\section{Sample M aryland Crop-Share L ease}

This lease is entered into on 20 , between:

Landowner(s) (hereinafter L essor):

whose mailing address is

and

Tenant (s) (hereinafter L essee):

whose mailing address is

\section{Property Description}

Lessor agrees to rent and lease to L essee, to occupy and to use for agricultural purposes only, the following real estate located in the County of and the State of , and described as follows:

, commonly referred to as the

farm and consisting of approximately acres, together with all

buildings and improvements thereon belonging to the L essor, except

\section{Tenure of L ease}

The term of this lease shall be from , 20 , to 20 At the end of the term, Lessee must surrender possession of the property, unless both parties agree to extend the lease through an Extension. Extension should be in writing and signed by both L essor and Lessee. If an Extension is not agreed to within months before the end of the term this shall act as constructive notice of the intent to terminate the lease. 


\section{No Partnership}

It is agreed that this agreement is one of lease and not of partnership, and L essor shall not be or become responsible for any debts contracted by L essee.

\section{M odification of Agreement}

A ny modification of this lease or additional obligation assumed by either party in connection with this agreement shall be binding only if placed in writing and signed by each party or an authorized representative of each party.

\section{Assignment and Sublease}

This lease shall inure to the benefit and be binding upon the heirs, executors, successors, and assigns of the parties; provided, however, Lessee shall not sublease all or any part of the leased premises, or assign this lease agreement, without the prior, express, and written consent of Lessor; and if Lessee does sublease the premises or part of the premises or assign this lease agreement, such sublease or assignment shall be void unless L essor has given their prior, express, and written consent.

\section{Right to Entry}

Lessor, as well as agents and employees of Lessor, reserve the right to enter the property at any reasonable time to: a) consult with the Lessee; b) make repairs, improvements, and inspections; c) after notice of termination of the lease is given do tillage, seeding, fertilizing, and any other customary seasonal work, including planting a cover crop, none of which is to interfere with the Lessee in carrying out L essee's regular farm operations.

\section{Division of Crops}

Lessee agrees to pay to L essor or L essor's agent or representative for rent the following shares of crops grown:

\begin{tabular}{|l|l|}
\hline Crop Grown: & Lessor's Share: \\
\hline & \\
\hline & \\
\hline & \\
\hline & \\
\hline
\end{tabular}




\section{Division of Expenses}

Lessor agrees to pay the following share of these expenses:

\begin{tabular}{|l|l|}
\hline Expense: & Lessor's Share: \\
\hline & \\
\hline & \\
\hline & \\
\hline & \\
\hline & \\
\hline & \\
\hline
\end{tabular}

\section{Labor}

Lessee shall be solely responsible for all employer obligations on hired labor with respect to safety requirements and social security and workers' compensation contributions, and the Lessor shall have no responsibilities therefore.

\section{Government Programs}

B oth L essor and Lessee will agree each crop year on the federal and state farm program payments to participate in and on the appropriate way to split any proceeds and costs incurred from program participation. Government programs can include conservation, commodity, and disaster programs offered by the federal, state, county, or local governments. This agreement will need to be in writing and signed by both parties.

\section{Crop Insurance}

Lessor and Lessee agree to split crop insurance premium payments and claims based on their respective share in each crop grown.

\section{Cultivation}

Lessee shall cultivate the demised premises according to generally accepted agricultural practices practiced in the County of State of

\section{Noxious Weeds}

Lessee agrees to use diligence to prevent noxious weeds from going to seed on the property. 


\section{Repairs}

Lessor and Lessee agree to the following:

1. Lessee agrees to prevent waste, loss, or damage to the property of L essor and keep property neat and orderly. Lessee further agrees to keep the building, fences (including hedges), and other improvements in good repair and condition as they are when L essee takes possession or in as good repair and condition as they may be put by Lessor during the term of the lease - ordinary wear, loss by fire, or unavoidable destruction excepted.

2. Lessor agrees to replace or repair as promptly as possible the dwelling or any other building or equipment regularly used by the operator that may be destroyed or damaged by fire, flood, or other cause beyond the control of the operator or to make rental adjustments in lieu of replacements. Lessor further agrees to furnish materials for all normal maintenance and repairs.

\section{Removal of Improvements}

Lessor agrees to let $L$ essee make minor improvements of a temporary or removable nature, which do not alter the condition or appearance of the property, at the Lessee's expense. Lessor further agrees to let the operator remove such improvements even though they are legally fixtures at any time this lease is in effect or within days thereafter, provided the operator leaves in good condition that part of the property from which such improvements are removed. Lessee shall have no right to compensation for improvements that are not removed except as mutually agreed.

\section{Mineral and Wind/Solar Development}

Lessor shall retain the right to enter into agreements for the development of petroleum, wind, solar, or other resources on the property, and may also authorize third parties to enter the property to survey, construct, and/or operate the facilities reasonably necessary to develop those resources. Lessor agrees to reimburse Lessee for any actual damage suffered for crops destroyed by these activities and to release L essee from obligation under the lease to continue farming this property when and if development of such resources interferes materially with Lessee's opportunity to make a satisfactory return.

\section{Modification of Agreement}

A ny modification of this agreement or additional obligation assumed by either party in connection with this agreement shall be binding only if placed in writing and signed by each party or an authorized representative of each party.

\section{Insurance} in liability insurance on the property. 


\section{Conservation}

B oth L essor and L essee agree to implement as far as possible the best management practices recommended by the $\mathrm{N}$ atural Resource Conservation Service and their respective Soil Conservation District with those agencies' soil and water conservation programs.

\section{Environmental Compliance}

The Lessee shall conduct all operations on the property in a manner consistent with all applicable local, state, and federal environmental codes, regulations, and statutes and shall bear sole responsibility for any violations thereof. The L essee shall be solely responsible for securing any permits or approvals necessary for his or her activities on the property. In the event of any legally prohibited release of materials to the environment, the Lessee will indemnify the Lessor for any costs of environmental cleanup and restoration as well as any penalties, fines, judgments or other amounts incurred by Lessor as a result of such release.

\section{Mediation}

A Il claims and disputes arising under or relating to this lease are to be first submitted for mediation through the $\mathrm{M}$ aryland A gricultural Conflict Resolution Service. B oth parties shall equally share the mediator's costs and fees. This provision maybe enforced by any court of competent jurisdiction and the party seeking enforcement may seek all costs, fees, and expenses associated with enforcing this provision.

\section{Entire Agreement}

This lease shall constitute the entire agreement between the parties and any prior understanding or representation of any kind preceding the date of this agreement shall not be binding upon either party except to the extent incorporated in this lease. 
Lessor

Lessor

Lessee

Lessee
Date

Date

Date

Date 


\section{SAMPLE MARYLAND FLEX CASH RENT FARM LEASE}

\section{DIRECTIONS:}

1. Complete two copies of this lease, one for the landlord and one for the tenant.

2. Make sure both parties agree on base rent, base yield, and base price when necessary.

3. Cross out or delete any unnecessary clauses.

4. Have both parties sign both copies, or sign one lease and make a copy of the signed lease.

5. This lease is provided to aid landlords and tenants in preparing their own written farm leases.

Disclaimer: This lease sample is intended to provide general information and should not be construed as providing legal advice. Using any lease format creates or alters the legal rights between the two parties and both parties should each consider consulting their respective attorneys for clarification on how any clause in a lease affects their respective legal rights.

This lease is based off a fixed cash rent lease and flex-cash rent lease clause developed by the North Central Farm Management Extension Committee and found at http://aglease101.org/DocLib/docs/ NCFMEC-01A.pdf modifications have been made to make the lease more Maryland specific. 


\section{Sample M aryland Flex C ash L ease}

This lease is entered into on , 20 , between:

L andowner(s) (hereinafter Lessor):

whose mailing address is

and

Tenant (s) (hereinafter L essee):

whose mailing address is

\section{Property Description}

Lessor agrees to rent and lease to Lessee, to occupy and to use for agricultural purposes only, the following real estate located in the County of and the State of , and described as follows:

, commonly referred to as the

Farm and consisting of approximately acres, together with all

buildings and improvements thereon belonging to the L essor, except

\section{Tenure of L ease}

The term of this lease shall be from , 20 , to 20_-_. This lease shall continue in effect from year to year thereafter unless written notice of termination is given by either party to the other at least days prior to expiration of this lease or the end of any year of continuation.

\section{No Partnership}

It is agreed that this agreement is one of lease and not of partnership, and Lessor shall not be or become responsible for any debts contracted by L essee. 


\section{M odification of Agreement}

A ny modification of this lease or additional obligation assumed by either party in connection with this lease shall be binding only if placed in writing and signed by each party or an authorized representative of each party.

\section{Assignment and Sublease}

This lease shall inure to the benefit and be binding upon the heirs, executors, successors, and assigns of the parties; provided, however, L essee shall not sublease all or any part of the leased premises, or assign this lease, without the prior, express, and written consent of Lessor; and if L essee does sublease the premises or part of the premises or assign this lease, such sublease or assignment shall be void unless Lessor has given their prior, express, and written consent.

\section{Right to E ntry}

L essor, as well as agents and employees of Lessor, reserve the right to enter the property at any reasonable time to: a) consult with the Lessee; b) make repairs, improvements, and inspections; c) after notice of termination of the lease is given do tillage, seeding, fertilizing, and any other customary seasonal work, including planting a cover crop; and d) hunt and fish wildlife during applicable seasons and according to the laws, rules, and regulations of the $\mathrm{M}$ aryland Department of $\mathrm{N}$ atural Resources, none of which is to interfere with the L essee in carrying out L essee's regular farm operations.

\section{Mineral and Wind/Solar Development}

L essor retains the right to enter into agreements for the development of petroleum, other minerals, wind, solar, or other resources on the property, and may also authorize third parties to enter the property to survey, construct, and/or operate the facilities reasonably necessary to develop those resources. Lessor agrees to reimburse L essee for any actual damage suffered to crops destroyed by these activities and to release Lessee from obligation to continue farming this property when and if development of such resources interferes materially with Lessee's opportunity to make a satisfactory return.

\section{Cultivation}

Lessee shall cultivate the demised premises according to generally accepted agricultural practices practiced in the County of State of

\section{Noxious Weeds}

L essee agrees to use diligence to prevent noxious weeds from going to seed on the property. 


\section{Repairs}

Lessor and Lessee agree to the following:

1. Lessee agrees to prevent waste, loss, or damage to the property of Lessor and keep property neat and orderly. Lessee further agrees to keep the building, fences (including hedges), and other improvements in good repair and condition as they are when L essee takes possession or in as good repair and condition as they may be put by Lessor during the term of the lease - ordinary wear, loss by fire, or unavoidable destruction excepted.

2. Lessor agrees to replace or repair as promptly as possible the dw elling or any other building or equipment regularly used by the operator that may be destroyed or damaged by fire, flood, or other cause beyond the control of the Lessee or to make rental adjustments in lieu of replacements. L essor further agrees to furnish materials for all normal maintenance and repairs.

\section{Removal of Improvements}

Lessor agrees to let $L$ essee make minor improvements of a temporary or removable nature, which do not al ter the condition or appearance of the property, at the L essee's expense. Lessor further agrees to let the operator remove such improvements even though they are legally fixtures at any time this lease is in effect or within days thereafter, provided the operator leaves in good condition that part of the property from which such improvements are removed. Lessee shall have no right to compensation for improvements that are not removed except as mutually agreed.

\section{Modification of Agreement}

A ny modification of this agreement or additional obligation assumed by either party in connection with this agreement shall be binding only if placed in writing and signed by each party or an authorized representative of each party.

\section{Environmental Compliance}

The L essee shall conduct all operations on the property in a manner consistent with all applicable local, state, and federal environmental codes, regulations, and statutes and shall bear sole responsibility for any violations thereof. The Lessee shall be solely responsible for securing any permits or approvals necessary for his or her activities on the property. In the event of any legally prohibited release of materials to the environment, the L essee will indemnify the Lessor for any costs of environmental cleanup and restoration as well as any penalties, fines, judgments or other amounts incurred by Lessor as a result of such release. 


\section{Conservation}

B oth L essor and L essee agree to implement as far as possible the best management practices recommended by the $\mathrm{N}$ atural Resource Conservation Service and their respective Soil Conservation District with those agencies' soil and water conservation programs.

\section{Mediation}

A Il claims and disputes arising under or relating to this L ease are to be first submitted for mediation through the $M$ aryland A gricultural Conflict Resolution Service. B oth parties shall equally share the mediator's costs and fees. This provision maybe enforced by any court of competent jurisdiction and the party seeking enforcement may seek all costs, fees, and expenses associated with enforcing this provision.

\section{Insurance}

L essee agrees to carry at a minimum \$ in liability insurance on the property. Lessee also agrees to carry a minimum coverage level of crop insurance on any crop produced on the property. Lessee agrees to supply Lessor with Certificates of Insurance and give notice of termination of coverage. Lessee will also name Lessor as an additional insured on any policy on the property.

\section{Flex Cash Rent}

B oth parties agree to 0 ption as a method for calculating rent on the farm. Cash rent on pastureland shall be fixed at \$ per acre for acres, or \$ total in pastureland rent.

Please mark the option chosen:

Option 1: Flexing Y ield Only

\begin{tabular}{|c|c|c|c|c|}
\hline Crop(s) & B ase Rent & $*($ Current $Y$ ield $\div$ B ase $Y$ ield $)$ & $=$ & Rent per acre \\
\hline & $\$$ & $*($ & 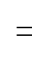 & $\$$ \\
\hline & $\$$ & --_ $)$ & $=$ & $\$$ \\
\hline - & $\$$ & $*($ & $=$ & $\$$ \\
\hline & $\$$ & $*($ & $=$ & $\$$ \\
\hline
\end{tabular}

Option 2: Flexing Price Only

$\begin{array}{lllll}\text { Crop(s) } & \text { Base Rent } & *(\text { Current Price } \div \text { B ase Price }) & = & \text { Rent per acre } \\ & \$ & *(\end{array}$




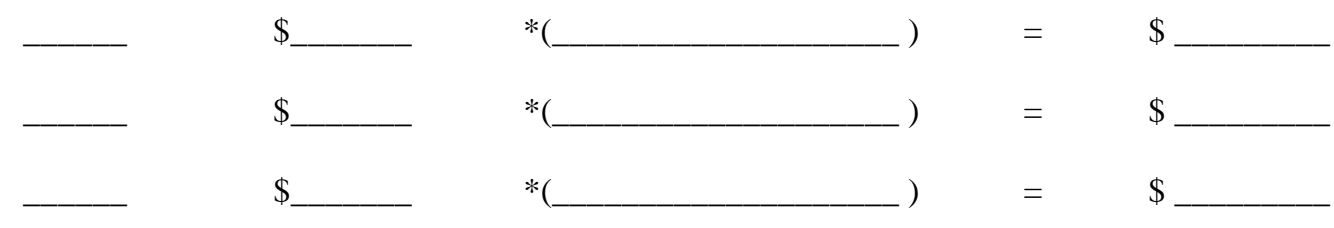

Option 3: Flexing Y ield and Price

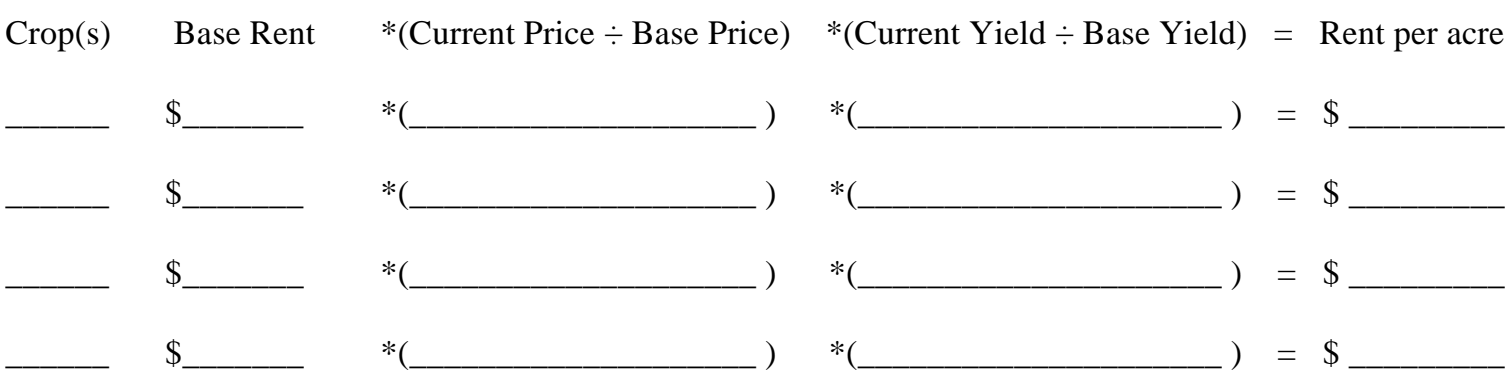

The fixed cash pasture rent payment and the flex cash rent payment will be due by day of of each year until this agreement is terminated.

\section{Entire Agreement}

This agreement shall constitute the entire agreement between the parties and any prior understanding or representation of any kind preceding the date of this agreement shall not be binding upon either party except to the extent incorporated in this agreement 
Date

Lessee

Date

Lessee

Date 


\section{Sample Termination Letter}

Date:

To:

Y ou are being given notice of an intent to terminate the lease on agricultural property described as:

. This tenancy will terminate on the first day of , 20

Y ou will therefore take notice to govern yourself accordingly.

Sincerely ,

Print Name

Signature 


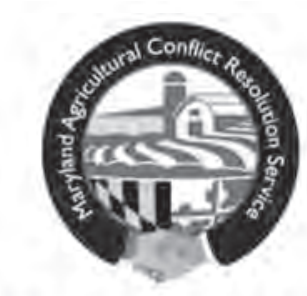

Farm, Agricultural \& Rural Mediation Services

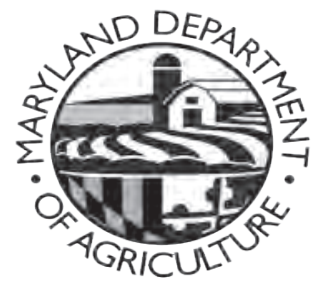

Maryland Department of Agriculture

50 Truman Parkway, A nnapolis, M D 21401

Phone: 410-841-5778 Fax: 410-841-5987

E-mail: mae.johnson@ maryland.gov

\section{MEDIATION INFORMATION SHEET}

\section{What Is M ediation?}

Mediation is a voluntary, no-cost to low-cost, non-adversarial process through which a neutral third party is introduced into discussion and negotiations between conflicting parties. M ediation provides a confidential setting that encourages individuals to take responsibility for solving their own problems. M ediation identifies and seeks agreement on the facts, agreement on the problem(s) to be solved and the creation of options to solve the problems. A successful mediation is almost always based on the voluntary cooperation and participation of all the parties.

\section{What Is A M ediator?}

A mediator has been trained to work with individuals and organizations in identifying mutually acceptable solutions to shared problems. The mediator is not a judge, but is there to direct the mediation process and stimulate communication between the involved parties. Through the process, there is no finding of right or wrong and the mediator has no power to impose a solution. The mediator will work with the parties to develop mutually acceptable and feasible options.

A $n$ agricultural mediator has additional training related to the kinds of problems related to agricultural issues. The process is based on fairness, integrity and the mediator's skill in helping agricultural producers, agencies, companies and $\mathrm{M}$ aryland citizens to arrive at their own solutions to their problems.

\section{Why M ediate?}

Mediation is an alternative process to taking a particular conflict to court and incurring burdensome legal expenses or filing an appeal. Participants in the mediation process create their own solution. The mediator does not arbitrate the settlement. Flexibility in considering a full range of realistic options is encouraged in the solution process. The fact that disputing parties are meeting together in the same room for the purpose of working out a solution to the particular problem(s) enables everyone to deal openly and knowledgeably with the full array of issues. All steps are taken to ensure confidentiality. 


\section{Steps in A gricultural M ediation}

1. An agricultural producer or an organization or individual with a dispute concerning agricultural or agriculturally related issues may request mediation by contacting the Maryland Agricultural Conflict Resolution Service (M aryland A CReS) and completing the form entitled "R equest for V oluntary M ediation."

2. Maryland ACReS staff will confirm that the other party (or parties) is willing to participate in mediation. A brief description of the situation is gathered by the M ediation Coordinator to prepare a briefing report for the mediator.

3. A mediator is assigned by the M ediation Coordinator.

4. All the parties are notified as to the date, time and neutral location of the mediation session.

5. M ost mediation sessions will be concluded in two to three hours unless everyone agrees that more time is needed.

\section{What $\mathrm{H}$ appens In A M ediation Session?}

1. The mediator is in charge of the session and arranges the room and participant seating to promote effective communication.

2. The mediator welcomes all parties and introductions take place.

3. The mediator establishes ground rules for the conduct of the session.

4. Each participant is given the opportunity to make a brief opening statement concerning the problem or his/her involvement in the particular relationship.

5. Following this, time is allowed for each participant to briefly express his/her feelings associated with the conflict.

6. Next, the issues are clarified, relevant data is considered, and desirable actions begin to be examined.

7. A $n$ exploration of the options and the consequences leads toward problem solving.

8. The mediator records agreements reached based on input from the parties.

\section{What H appens If An A greement Is N ot R eached?}

If a final agreement cannot be reached, the outcome will simply be an "as was" situation before mediation began with one difference... everyone involved will have a better understanding of their own and others' perspectives, will have explored several options and have a fuller grasp of the situation and why a solution was not achievable. A II parties will retain their full set of options to seek a solution through legal or other means. At no time should the mediation process be considered a delaying tactic.

\section{W hat Does M ediation C ost?}

M ediation is a no-cost to low-cost means of resolving disputes, especially when compared with traditional legal processes. M aryland ACReS is administered by the MDA in cooperation with the US Department of A griculture. Consultation with M aryland A CR eS staff and the initial mediation session is at no charge. If additional mediation sessions are needed, costs are shared by the parties. Full or partial waivers of fees may be available based on income. A ny additional legal, financial or technical advisors, if needed, are paid by the participants.

MARTIN O'MALLEY, GOVERNOR ANTHONY G. BROWN, LT. GOVERnOr
EARL F. HANCE, SECRETARY

Mary Ellen Setting, Deputy Secretary 


\title{
Agricultural Leasing in Maryland
}

\author{
Written by: \\ Paul Goeringer \\ Research Associate \\ University of Maryland \\ Agricultural \& Resource Economics \\ pgoeringer@arec.umd.edu \\ Review and Comments By: \\ Shannon P. Dill \\ Extension Educator \\ University of Maryland Extension \\ Talbot County \\ sdill@umd.edu

\section{John East} \\ Mae C. Johnson \\ Mediation Coordinator \\ Maryland ACReS \\ Maryland Department of Agriculture \\ mae.johnson@maryland.gov
}

\author{
Dr. Loretta M. Lynch \\ Professor \& Director \\ Center for Agricultural \& Natural Resource Policy \\ Professor \& Extension Specialist, Land Policy \\ Agricultural \& Resource Economics \\ llynch@arec.umd.edu
}

\author{
Jennifer L. Rhodes \\ Extension Educator \\ University of Maryland Extension \\ Queen Anne's County \\ irhodes@umd.edu
}

\section{Steve Connelly}

Agricultural Marketing Specialist

Crop Insurance Education \& Promotion

Maryland Department of Agriculture

Steve.connelly@maryland.gov

Issued in furtherance of Cooperative Extension work, acts of May 8 and June 30, 1914, in cooperation with the U.S. Department of Agriculture, University of Maryland, College Park, and local governments. Cheng-i Wei, Director of University of Maryland Extension.

The University of Maryland is equal opportunity. The University's policies, programs, and activities are in conformance with pertinent Federal and State laws and regulations on nondiscrimination regarding race, color, religion, age, national origin, gender, sexual orientation, marital or parental status, or disability. Inquiries regarding compliance with Title VI of the Civil Rights Act of 1964, as amended; Title IX of the Educational Amendments; Section 504 of the Rehabilitation Act of 1973; and the Americans With Disabilities Act of 1990; or related legal requirements should be directed to the Director of Human Resources Management, Office of the Dean, College of Agriculture and Natural Resources, Symons Hall, College Park, MD 20742. Written in 2012 



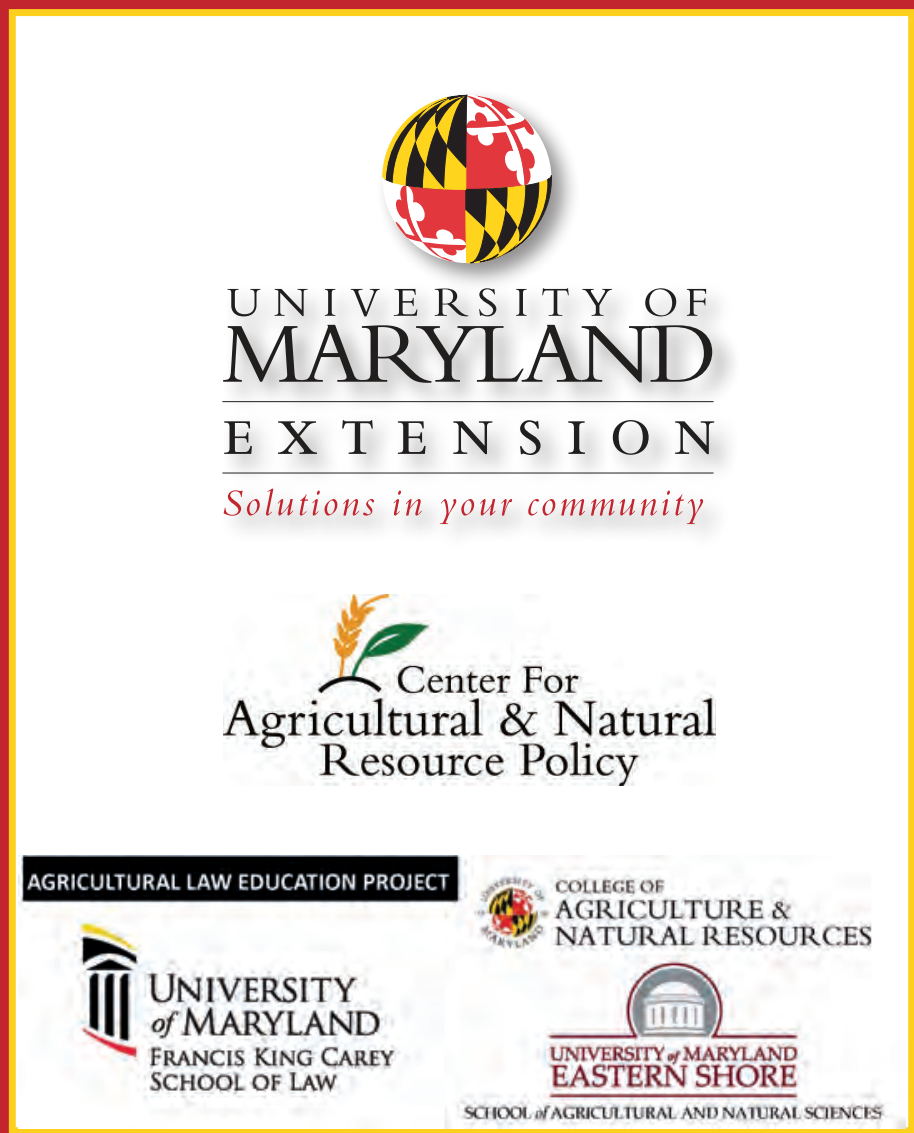

